\title{
Pelaksanaan Pasal 43 Undang-Undang Nomor 4 I Tahun 2004 Mengenai Pengelolaan Harta Wakaf di Pondok Modern Darussalam Gontor
}

\author{
Mansur Efendi \\ IAIN Surakarta \\ mansur.iainsolo@gmail.com
}

\begin{abstract}
Abstrak
Law No. 41 of 2004 about waqf has provided space in the management of productive waqf. Article 43 stated that the management and development of waqf was carried out productively. This showed that many parties hope that the benefits of productive waqf can be presented in real life. Furthermore, the spirit of the Waqf Law is emphasizing that waqf was an instrument for managing productive assets for the public interest. But in reality, waqf management has not been done productively. Although productive waqf management has begun, the numbers was still small. Many parties have complained about the obstacles faced in managing productive waqf. This paper illustrated the implementation of Law No. 41 of 2004, particularly Article 43 about productive waqf in Pondok Modern Darussalam Gontor. Before this law was issued, Pondok Gontor had developed productive waqf for social purposes. Productive waqf management in Pondok Modern Darussalam Gontor was expected to be one of the models for waqf managers in Indonesia. Thus, the technical obstacles of managing productive waqf can be reduced.
\end{abstract}

Kata kunci: waqf law, productive waqf, Pondok Modern Darussalam Gontor

Pendahuluan

Wakaf merupakan salah satu instrumen keuangan syariah dengan akar sejarah yang panjang. Wakaf sendiri sudah dipraktikkan sejak masa Rasulullah Saw, yang kemudian dilanjutkan para sahabat dan terus berkembang hingga sekarang. Indonesia sendiri, memiliki potensi wakaf yang cukup tinggi. Dilihat dari jumlah tanah wakaf di Indonesiayang mencapai 3,49 milyar $\mathrm{m}^{2}$ atau sekitar 34.900 hektar (ha) yang tersebar di 420.003 titik lokasi di seluruh Indonesia, maka ini merupakan harta wakaf terbesar di dunia (Kementrian 
Agama Republik Indonesia Direktorat Jendral Bimbingan Masyarakat Islam Direktorat Pemberdayaan Wakaf 2013).

Wakaf merupakan jenis ibadah muta'addiyah (ibadah sosial) yang manfaatnya dapat dirasakan oleh wakif serta orang lain di sekitarnya. Ibadah sosial tersebut memiliki tempat yang khusus dan istimewa di sisi Allah SWT. Manfaatwakaf yang besar ini, secara teoritik bisa dijelaskan bahwa wakaf dapat menjadi instrumen penting pengendalian harga. Selain itu, keberadaan wakaf juga akan menyebabkan kapasitas produksi bertambah yang akan menguntungkan masyarakat.Kemampuan wakaf dalam menaikkan kapasitas produksi dapat dijelaskan dengan menggunakan teori Production Possibility Frontier (PPF) (DEKS Bank Indonesia dan DES FEB UNAIR 2016).

Pengelolaan wakaf di beberapa negara menunjukkan kemajuan yang signifikan. Arab Saudi misalnya, pengelolaan harta wakaf ditunjukkan dengan perluasan al-Haramain al-Syarifain. Selain itu juga dengan melakukan pembangunan masjid dan berbagai sarana pendidikan seperti perpustakaan serta penerbitan buku gratis. Bahkan pengelolaan harta wakaf juga diarahkan pada fasilitas jalan umum seperti tol dari Jeddah ke Mekah dan jembatan al-Mina.Pengembangan wakaf juga sudah merambah pada bentuk saham, pertokoan serta perhotelan, dan salah satu yang terkenal adalah Zam-zam Tower.Zam-zam Tower adalah menara yang berada di Mekah, tepatnya di sekitar Masjidil Haram. Zam-zam Tower berdiri di atas tanah yang diwakafkan oleh Raja Arab Saudi, di bawah pengelolaan King Abdul Azis Waqf (KAAW) sebagai nazhir. Tanah wakaf tersebut disewakan kepada Binladin Group dengan sistem konsesi yang kemudian disebut sebagai BOT (Buid-Operate-Transfer) dengan jangka waktu hingga 28 tahun. Pembiayaan megaproyek tersebut mencapai US\$ 390.000.000 dengan menerbitkan sukuk Intifa'a dengan jangka waktu 24 tahun. Sukuk Intifa'a sendiri merupakan sejenis sukuk yang memungkinkan pembelinya dapat menyewa ruang yang berada di dalam kompleks Zam-zam Tower selama jangka waktu tertentu (DEKS Bank Indonesia dan DES FEB UNAIR 2016).

Di Malaysia, pengembangan wakaf diarahkan pada pembangunan infrastruktur pendidikan dan kesehatan. Salah satunya adalah pembangunan layanan pendidikan dengan 19 klinik wakaf al-Nur yang tersebar di Johor, Negeri Sembilan, Selangor, Serawak, Perak dan Pulai Pinang, serta satu buah rumah sakit di Johor. Pelayanan kesehatan ini diperuntukkan bagi masyarakat miskin dengan biaya yang murah. Selain menyediakan pelayanan kesehatan, pengembangan harta wakaf juga digunakan untuk membangun perumahan bagi masyarakat miskin, misalnya adalah Perumahan al-Ehsan di Malaka. Di bidang pendidikan, dana wakaf juga digunakan untuk membangun Sekolah Agama Rakyat (SAR), Sekolah Agama Negeri (SAN), Kolej Islam Malaya yang saat ini dikenal dengan Universiti Islam Malaysia di Cyberjaya, Universiti Antarabangsa Al-Bukhari di Kedah, dan Akademi Kuliner Trengganu. Selain mengelola wakaf yang berasal dari harta tidak bergerak, pengembangan wakaf juga 
dilakukan dengan memperkenalkan konsep saham wakaf.Mekanisme saham wakaf ini adalah nazhir menghimpun dana dari masyarakat berupa wakaf uang atau penggantian aset wakaf yang lama dengan saham wakaf, dimana perlembar saham dihargai RM 10. Beberapa proyek yang dibiayai dari saham wakaf ini antara lain Bangunan Saham Wakaf Johor, bangunan ini merupakan ruang kantor yang disewakan kepada perusahaan maupun pemerintah. Selain itu juga untuk membiayai proyek wakaf perkebunan kelapa sawit seluas 3.800 hektar. Lebih dari itu, saham wakaf juga digunakan untuk pengadaan asrama pelajar di Mesir. Asrama berlantai enam di daerah Qahirah, Mesir tersebut dibeli pada tahun 2006. Adapun proyek pembeliannya dilakukan dengan pengumpulan dana senilai RM 4.500.000 melalui saham wakaf (DEKS Bank Indonesia dan DES FEB UNAIR 2016).

Pengelolaan harta wakaf di Singapura juga berkembang dengan pesat, bahkan pengembangannya dilakukan dengan model yang inovatif dan profesional.Aset-aset wakaf dibiayai melalui patungan antara Baitul Mal yang dikelola MUIS dan pembiayaan internal dari nazhir. Selain itu, aset wakaf juga dibiayai melalui peluncuran sukuk atau obligasi syariah di pasar modal dengan akad musyarakah atau bagi hasil yang diberi nama "Musharakah Bond". Aset-aset wakaf di Singapura tidak hanya berupa masjid, namun juga aset produktif. Aset tersebut antara lain Wakaf Jabbar di Duku Road yang berupa kompleks perumahan dengan sewa tahunan mencapai 36.000 dolar Singapura per tahun (tahun 2005). Selain itu juga properti di daerah Telok Indah, di kawasan ini berdiri masjid, kompleks pertokoan dan 20 unit apartemen. Keuntungan yang dihasilkan oleh aset wakaf produktif tersebut disalurkan ke sektor sosial dan keagamaan.Pengelolaan harta wakaf di Singapura dilakukan oleh Majlis Ugama Islam Singapura (MUIS). Dalam pengelolaannya, MUIS bersifat inklusif dengan membuka kesempatan yang luas bagi para profesional yang ingin berkecimpung di bidang perwakafan. Divisi pengelolaan wakaf MUIS misalnya tidak hanya melibatkan ahli syariah, namun juga insinyur teknik sipil, arsitek, tenaga surveyor profesional (DEKS Bank Indonesia dan DES FEB UNAIR 2016).

Pengelolaan wakaf produktif di Indonesia, sebenarnya sudah mendapatkan payung hukumnya. Melalui Undang-undang No. 41 Tahun 2004 tentang wakaf, sebenarnya pengelolaan wakaf diarahkan pada sektor produktif. Ini menegaskan bahwa manfaat wakaf harus benar-benar dapat dirasakan oleh publik. Ini mengingat obyek harta wakaf memang bersifat komersial, sehingga wakaf sebenarnya memiliki nilai ekonomis yang tinggi.

Pelaksanaan wakaf produktif di Indonesia sendiri sudah dimulai, namun demikian jumlahnya masih cenderung sedikit. Masih banyak kendala yang dihadapi sehingga pelaksanaan wakaf produktif belum optimal. Peruntukan wakaf masih banyak didominasi untuk peribadatan, seperti masjid, langgar dan surau.Sementara peruntukan harta wakaf di sektor produktif jumlahnya masih sedikit. 
Dari sekian banyak pengelola wakaf produktif, Pondok Modern Darussalam Gontor, Jawa Timur merupakan salah satunazhir yang relatif berhasil. Pondok Modern Darussalam Gontor sejak awal perkembangannya telah menyebut dirinya sebagai "pesantren wakaf". Pesantren ini merupakan wakaf Trimurti, yang secara resmi pada tanggal 12 Oktober 1958 diserahkan Trimurti kepada masyarakat yang diwakili oleh Badan Wakaf Pondok Modern Darussalam Gontor (Zarkasyi 2005). Hasil Penelitian Center for Study of Riligion and Culture (CSRC) UIN Syarif Hidayatullah Jakarta menyebutkan bahwa Pondok Modern Darussalam Gontor dianggap berhasil memanfaatkan hasil wakaf produktifnya untuk membiayai dirinya dan karenanya dapat dijadikan model bagi pengembangan lembaga pendidikan berbasis wakaf (Huda 2012).

Berangkat dari eksplorasi di atas, pengembangan wakaf di Indonesia perlu diarahkan pada sektor yang lebih produktif sehingga manfaat harta wakaf dapat dirasakan secara berkelanjutan.Karena itu, dalam penelitian ini akan dijelaskan tentang kajian hukum wakaf produktif, serta pelaksanaannya di Pondok Modern Darussalam Gontor. Penelitian ini menjadi penting dan strategis, mengingat banyak aset wakaf yang belum terkelola dengan baik. Lebih dari itu, banyak kendala yang dihadapi oleh nadzir, sehingga pengelolaan wakaf produktif cenderung belum optimal. Pelaksanaan wakaf produktif di Pondok Modern Darussalam Gontor, diharapkan dapat menjadi model pengelolaan wakaf produktif di Indonesia.

\section{Metode}

Jenis penelitian ini adalah penelitian empiris (empirical research). Pendekatan yang digunakan adalah pendekatan perundang-undangan (statue approach). Pendekatan perundang-undangan sendiri merupakan pendekatan yang meletakkan norma atau kaidah hukum tertentu sebagai dasar dalam melakukan kajian pada masalah yang diteliti. Secara teknis, pendekatan ini dilakukan dengan menelaah peraturan perundangan-undangan dan regulasi yang berkaitan dengan masalah yang diangkat (Marzuki 2007).

Lokasi penelitian ini di Pondok Modern Darussalam Gontor, Ponorogo, Jawa Timur. Pengumpulan bahan hukum dilakukan melalui studi pustaka yang terdiri atas aturan perundang-undangan dan literatur lainnya. Sedangkan untuk mendapatkan data pelaksanaan pengelolaan harta wakaf, peneliti menggunakan metode wawancara.

\section{Sumber Daya Manusia (SDM) Nadzir Wakaf}

Pengelolaan harta wakaf di Pondok Modern Darussalam Gontor memiliki akar sejarah yang panjang. Bagi keluarga pendiri pondok, kata"wakaf"telah menjadi redaksi yang sakral. Pada tahun 1936, Trimurti Pondok Modern Darussalam Gontormenyatakan 
bahwa, "siap pikir, siap bahu, siap bondo. Yen perlu siap nyawa". Kata "nyawa"menunjukan ikrar wakaf bagi para pendiri pondok yang harus siap untuk menyerahkan segenap jiwa dan raganya untuk pengembangan pendidikan melalui wadah pesantren atau yang kemudian disebut sebagai wakaf diri. Husnan Bey Fananie yang merupakan cucu K.H. Zainuddin Fanani (salah satu Trimurti) dalam wawancara yang telah dilaksanakan pada tanggal 9 Juni 2019 memaparkan bahwa:

"Beliau (Trimurti) mengikrarkan dirinya, hartanya, jiwanya serta keturunannya untuk diwakafkan untuk umat. Dan yang paling memiliki tanggung jawab atas keberlangsungan harta wakaf itu ialah keluarga keturunan pendiri pondok. Sehingga jangan sampai asetaset wakaf itu rusak atau cacat dan jangan sampai terkhianati."

Menurut peneliti, ikrar Trimurti Pendiri Pondok Modern Darussalam Gontor tersebut merupakan komitmen dalam pengelolaan dan pengembangan harta wakaf. Komitmen yang mampu melahirkan energi secara terus menerus, sehingga terwariskan kepada keturunan Trimurti. Tidak hanya keturunan Trimurti, komitmen yang sama juga tumbuh dari kalangan Pondok Modern, baik dari ustadz maupun alumninya. Bahkan peserta wakaf diri tidak hanya berasal dari keturunan Trimurti, melainkan juga unsur di luar keluarga Pendiri Pondok Modern. Ini menunjukkan betapa proses transformasi gagasan dan semangat pengelolaan wakaf berjalan dengan sangat baik.

Ikrar Trimurti setidaknya mengandung tiga pesan. Pertama, pengelolaan dan pengembangan diarahkan pada tujuan yang jelas, yaitu pengembangan pendidikan melalui wadah pesantren. Kedua, pengelolaan harta wakaf tidak cukup hanya ditopang dengan aspek ekonomis (finansial). Lebih dari itu, pengelolaan wakaf menuntut semua potensi (jiwa dan raga) yang dimiliki oleh nadzir. Ketiga, pengelolaan dan pengembangan harta wakaf adalah proses panjang sehingga membutuhkan regenerasi. Untuk memastikan keberlangsungan pengelolaan wakaf tetap berjalan, maka Trimurti melakukan upaya regenerasi Sumber Daya Manusia (SDM) yang unggul melalui kaderisasi di Pondok Modern Darussalam Gontor.

Kaderisasi yang dilakukan mampu melahirkan SDM unggul, yang siap mengabdi untuk pondok. Terdapat sesuatu yang menarik dari jenis wakaf yang dicanangkan oleh Pondok Modern Darussalam Gontor,yaitu adanya wakaf diri atau jiwa. Sebagaimana yang diungkapkan oleh ketua YPPWPM, Imam Sobari dalam wawancara yang telah dilakukan pada tanggal 11 Juni 2019:

"Wakaf diri/jiwa mungkin itu memang yang membedakan dengan yang lain. Karena yang namanya wakaf jiwa ini bisa mengelola semua wakaf-wakaf yang ada. Jikalau tidak ada wakaf jiwa, mungkin tidak akan bisa terkelola dengan baik seluruh wakaf itu karena kembali hal ini kembali kepada kemampuan nadzir."

Para santri-santri senior setiap tahun mewakafkan dirinya ke Pondok Gontor selama satu tahun. Guru (ustadz) dan dosen sebagiannya mewakafkan diri untuk beberapa tahun 
lamanya (mu'aqqat) dan sebagian lagi mewakafkan untuk selama-lamanya (mu'abbad). Guru dan dosen yang mewakafkan diri untuk selama-lamanya adalah kader-kader Pondok Gontor pilihan yang secara sukarela dan tidak ada paksaan dari pihak manapun. Mereka menyatakan bahwa seluruh hidupnya disediakan untuk mengabdi, membangun dan memajukan Pondok Modern Darussalam Gontor (Nice 2016).

Pondok Modern Darussalam Gontor mengakomodir wakaf diri dengan tujuan untuk menjamin kelangsungan hidup pondok dan memandangnya sebagai bagian dari wakaf jasa, karena pada dasarnya praktik wakaf yang demikian telah dilakukan oleh masyarakat. Ada dua istilah wakaf diri di Pondok Modern Darussalam Gontor, yaitu wakaf diri didalam pondok dan wakaf diri diluar pondok. Biasanya yang melakukan wakaf diri adalah para santri senior, guru (ustadz) dan dosen, ada yang mewakafkan diri untuk sementara (wakaf diri luar) dan ada yang mewakafkan diri untuk selama-lamanya (wakaf diri dalam) (Nice 2016).

Peneliti berpendapat bahwa upaya Pondok Modern Darussalam Gontor dalam membentuk SDM nadzir yang unggul, merupakan unsur fundamental dalam pengelolaan wakaf produktif. Melalui wakaf diri, Pondok Modern Darussalam Gontor justru membuktikan bahwa profesionalisme pengelolaan wakaf produktif tidak selalu diukur dari tingginya pendapatan finansial yang diterima oleh nadzir.

\section{Penghimpunan Harta Wakaf Berwawasan Wakaf Produktif}

Selain merumuskan arah pengembangan wakaf produktif yang jelas dan menyiapkan SDM unggul, pengelolaan wakaf produktif di Pondok Modern Darussalam Gontor juga mempertimbangkan aspek teknis. Aspek tersebut antara lain adalah jenis harta wakaf yang diterima, serta kemampuan nadzir dalam mengelola harta wakaf. Aspek tersebut sangat diperhatikan agar pengelolaan wakaf produktif dapat berjalan secara optimal.

Pengelolaan harta benda wakaf di Pondok ModernDarussalam Gontor diperankan oleh Yayasan Pemeliharaan dan Perluasan Wakaf Pondok Modern (YPPWPM). K.H Imam Sobari menjelaskan bahwa jenis harta benda wakaf yang dihimpun oleh YPPWPM tidak terbatas hanya berbentuk tanah saja, melainkan mengembangkan konsep yang lebih terbuka dan eksploratif. Jenis harta wakaf yang dikelola mencakup semua benda yang memiliki nilai ekonomis. Baik berupa benda-benda tidak bergerak (properti), benda-benda bergerak (komoditas), uang tunai dan juga berupa jasa pelayanan (wakaf diri/jiwa).

Berkaitan dengan jenis harta wakaf yang dikelola oleh Pondok Modern Darussalam Gontor, peneliti berpendapat bahwa penghimpunan harta wakaf sangat berwawasan wakaf produktif. Hal ini ditandai dengan konsep penghimpunan harta wakaf yang dilakukan, berorientasi pada harta yang memiliki nilai ekonomis. Dengan beragamnya jenis harta wakaf yang dihimpun, akan memudahkan nadzir dalam meningkatkan nilai ekonomisnya. 
Dalam pandangan Pondok Modern Darussalam Gontor, seluruh wakaf yang diserahkan ke pondok harus mempunyai syarat, yaitu wakaf yang tidak terikat atau tidak bersyarat. Ini berarti bahwa wakif tidak boleh menentukan peruntukan harta wakaf yang diserahkan kepada pondok. Sebagaimana diungkapkan oleh ketua YPPWPM, "Wakaf yang diberikan ke Pondok itu haruslah tidak bersyarat, jadi terserah pondok wakaf tersebut mau diapakan. Misalnya, saya ada tanah luasnya sekian hektar, ingin saya wakafkan jadi pondok, maka itu tidak boleh, karena bersyarat."

Wakif yang telah menyerahkan hartanya harus percaya sepenuhnya kepada nadzir, bahwa peruntukan harta wakaf disesuaikan dengan kebutuhan dan tujuan pondok. Dalam penghimpunan harta wakaf, diberlakukan juga studi kelayakan sebelum diputuskan apakah harta wakaf yang akan diserahkan oleh wakif diterima atau ditolak. Hal ini dilakukan agar aset yang dikelola bermanfaat bagi kemaslahatan umat.

Husnan Bey Fananie menjelaskan bahwa tidak semua tawaran aset wakaf diterima. Apabila memang hasil studi kelayakan tidak sesuai, maka permohonan wakaf akan ditolak. Misalnya, wakaf tanah di lingkungan non muslim. Berdasarkan studi kelayakan, apabila wakaf tersebut diterima, maka secara sosiologis justru akan melahirkan mudharat, maka permohonannya tidak diterima. Harta wakaf di pondok pesantren setiap tahunnya semakin meningkat jumlahnya. Pada saat ini luas total aset tanah wakaf yang dihimpun oleh Pondok Modern Darussalam Gontor hingga Juli 2019 seluas 1560 hektar.

Wakaf Pondok Modern Darussalam Gontor telah mendapat perhatian dari masyarakat luas, sehingga memperoleh sumber-sumber wakaf tidak hanya seperti tanah dan bangunan saja, melainkan menjangkau benda-benda bergerak seperti peralatan pertanian, hewan ternak, hewan potong, kendaraan, peralatan industri, mesin cetak dan lain-lainnya. Selain itu, dengan adanya YPPWPM, mampu memberikan kemudahan bagi Pondok Gontor untuk terus berupaya menggali potensi perekonomian, baik di dalam pondok maupun diluar pondok. Sehingga Pondok Modern Darussalam Gontor menjadikan pondok pesantren yang semakin mandiri terutama dalam hal pendanaan.Dengan banyaknya bantuan yang diberikan dari pihak luar kepada pondok, menandakan bahwa sumber-sumber wakaf produktif Pondok Modern Darussalam Gontor tidak terbatas pada benda-benda bergerak saja, melainkan bisa juga berupa hewan-hewan ternak dan hewan potong.

Harta benda wakaf yang dihimpun oleh Pondok Modern Darussalam Gontor adalah aset yang diserahkan secara penuh oleh wakif kepada nadzir tanpa syarat apapun. Secara tertulis terdapat klausul yang menyebutkan bahwa wakif menyerahkan aset wakaf pada Gontor sebagai nadzir, semata-mata hanya untuk kemaslahatan umat. Mengenai peruntukan aset wakaf dan teknis pengelolaannya diserahkan sepenuhnya oleh nadzir.

Dalam pandangan peneliti, kebijakan ini memungkinkan bagi Pondok ModernDarussalam Gontor untuk mengelola aset wakaf yang dimiliki sesuai dengan 
kemampuan nadzir. Dengan demikian, nadzir tidak dibebani dengan pengelolaan aset wakaf sesuai dengan keinginan wakif. Nampaknya inilah cara Pondok Modern Darussalam Gontor untuk memastikan bahwa aset wakaf yang dihimpun akan dikelola sesuai kemampuan nadzir. Harta wakaf yang dikelola sesuai kemampuan nadzir, akan berdampak pada naiknya nilai ekonomis harta tersebut. Keseluruhan aset wakaf yang diterima oleh pondok hanyalah aset-aset yang mampu untuk mengelolanya. Apabila nadzir tidak mampu untuk mengelolanya, maka harta wakaf tidak akan diterima.

\section{Penggunaan Harta Wakaf Secara Produktif}

Sesuai dengan ikrar wakaf yang telah diamanatkan oleh para pendiri (Trimurti) kepada Badan Wakaf Pondok Modern Darussalam Gontor, maka YPPWPM bertanggung jawab untuk mengelola dan mengembangkan tanah wakaf pondok sekaligus berusaha memberdayakan aset-aset wakaf tersebut agar berdayaguna yang hasilnya diperuntukkan untuk penunjang kebutuhan dan program-program pondok. Pondok Modern Darussalam Gontor berusaha memanfaatkan aset-aset wakaf tersebut kedalam bentuk unit-unit usaha kecil. Seluruh aset wakaf yang diperoleh tidak hanya dipergunakan untuk membangun sarana prasarana pendidikan dan pengajaran yang layak bagi para santri. Melainkan juga dibuat beberapa unit-unit usaha ini dikelola sendiri oleh para santri sekaligus sebagai upaya untuk memenuhi kebutuhan hidup pondok. Sampai saat ini Pondok Modern Darussalam Gontor sudah memiliki beberapa unit-unit usaha, seperti toko buku, percetakan, rumah sakit, perusahaan air mineral, dan lainsebagainya.

Sejak awal Pondok Gontor telah menggali sumber-sumber dana dengan mencoba mendirikan koperasi dan unit-unit usaha yang dijadikan alat pemberdayaan wakaf. Sejalan dengan cita-cita yang telah dicanangkan oleh para pendirinya, sebagian besar hasil dari aset wakaf seperti sawah, wakaf tersebut dipergunakan untuk kepentingan pondok. Proses pengelolaannya dilakukan dan diawasi oleh para nadzir yang umumnya adalah alumni pondok.

Penggunaan harta wakaf dilakukan secara produktif, dengan pendekatan yang cenderung protektif. Barang dan jasa yang dihasilkan digunakan untuk memenuhi kebutuhan ustadz dan santri. Dengan demikian, konsumen yang akan menikmati barang dan jasa tersebut adalah keluarga besar pondok, baik ustadz maupun santrinya. Dengan pendekatan seperti ini, konsumen yang menjadi pangsa pasar dari barang dan jasa yang dihasilkan sudah tersedia. Keuntungan yang dihasilkan dari pengelolaan wakaf produktif tersebut, digunakan untuk menunjang kebutuhan pondok.

Peneliti berpendapat bahwa kebijakan penggunaan harta wakaf (terutama tanah) oleh Pondok Modern Darussalam Gontor memang tidak jauh berbeda dengan kebanyakan penggunaan wakaf di Indonesia. Meskipun demikian, penggunaan harta wakaf 
yang cenderung protektif, menjadikan pengelolaan wakaf produktif di Pondok Modern Darussalam Gontor lebih optimal. Konsep ekonomi protektif memungkinkan harta wakaf dikelola secara produktif oleh nadzir pondok dalam menunjang kebutuhan pondok. Keuntungan yang dihasilkan digunakan untuk kepentingan pondok.

Sebagai salah satu solusi yang menjadikan wakaf lebih produktif, maka Pondok Modern Darussalam Gontor juga menerima wakaf uang. Langkah ini diambil untuk menciptakan investasi dalam memberikan pelayanan keagamaan, pelayanan pendidikan dan pelayanan sosial. Pelaksanaan wakaf uang bersumber dari wali santri berupa infaq yang dibayarkan setiap bulan, terdiri dari uang makan dan biaya SPP. Infaq dari wali santri diklaim sebagai wakaf, dengan alasan dana tersebut secara tidak langsung digunakan untuk operasional pondok. Karena sejak awal Pondok Modern Darussalam Gontor sudah mengklaim sebagai pesantren wakaf, maka segala bentuk amal yang dilakukan atas dasar aqad wakaf, seperti para guru yang mengabdi di pondok sebagai wujud wakaf diri. Yang semata-mata mewakafkan jasa dan pelayanannya kepada umat.

Pembayaran infak dari para wali santri dikelola melalui unit-unit usaha. Keuntungan dari unit-unit usaha tersebut dikembalikan lagi untuk pemenuhan hidup pondok. Di Indonesia sendiri, peluang wakaf uang sebenarnya cukup menjanjikan. Dari tahun ke tahun, penghimpunan wakaf uang menunjukkan trend kenaikan. Ini menjadi peluang bagi Pondok Modern Darussalam Gontor dalam meningkatkan penghimpunan wakaf uang.

\section{Distribusi Keuntungan Wakaf Produktif}

Distribusi hasil keuntungan wakaf produktif, diarahkan untuk mengembangkan dan memajukan Balai Pendidikan Pondok Modern Darussalam Gontor. Untuk mewujudkannya, maka dituangkan kedalam nilai-nilai Panca Jangka sebagai program kerja untuk memberikan pengarahan dan panduan untuk mewujudkan upaya pengembangan dan pemajuan pondok. Adapun nilai-nilai Panca Jangka tersebut adalah sebagai berikut (Pondok Modern Darussalam Gontor 2010):

a. Pendidikan dan Pengajaran

Jangka ini berusaha secara maksimal untuk meningkatkan dan menyempurnakan pendidikan dan pengajaran di Pondok Modern Darussalam Gontor. Dalam nilai ini, hasil wakaf pondok dipergunakan untuk memberikan subsidi kepada para santri yang bersumber dari biaya SPP.

b. Kaderisasi

Pondok Modern Darussalam Gontor memberikan perhatian terhadap upaya dalam menyiapkan kader-kader yang akan melanjutkan cita-cita pondok. Banyak pondok pesantren yang mengalami kemunduran, bahkan mati, disebabkan karena tidak adanya program kaderisasi yang baik. 
c. Pergedungan

Jangka ini memberikan perhatian kepada upaya penyediaan sarana prasarana pendidikan dan pengajaran yang layak bagi para santri. Pemeliharaan dan pembangunan sarana prasarana sebagian didanai dari hasil wakaf.

\section{d. Khizanatullah}

Diantara syarat terpenting bagi sebuah lembaga pendidikan agar tetap bertahan hidup dan berkembang adalah memiliki sumber dana sendiri. Sebuah lembaga pendidikan yang hanya menggantungkan hidupnya kepada bantuan pihak lain yang belum tentu didapat tentu tidak dapat terjamin keberlangsungan hidupnya. Di antara usaha yang telah dilakukan untuk memenuhi maksud ini adalah membentuk suatu badan khusus yang mengelola dana, yaitu YPPWPM.

e. Kesejahteraan Keluarga Pondok

Jangka ini bertujuan untuk memberdayakan kehidupan keluarga-keluarga yang membantu dan bertanggung jawab terhadap hidup dan matinya pondok secara langsung, sehingga mereka itu tidak menggantungkan penghidupannya kepada pondok. Program ini bertujuan untuk memberdayakan kehidupan keluarga pondok sehingga dapat mengabdi dan berjuang bagi pondok secara maksimal.

Pengelolaan keuntungan dari wakaf produktif diperoleh dari pertama, dari hasil pertanian yang digunakan untuk memenuhi kebutuhan pangan para santri dan guru-guru. Keuntungan dari hasil pertanian disetorkan ke pondok setiap enam bulan sekali. Kedua, dari keuntungan usaha-usaha kecil seperti minimarket yang digunakan untuk pengembangan usaha sekaligus untuk menopang kesejahteraan guru. Pada umumnya tidak ada istilah gaji bagi guru-guru di Pondok Modern Darussalam Gontor. Akan tetapi para guru-guru tersebut diberikan kesejahteraan dengan standar sekadar untuk bekal beribadah atau bekal mengabdi di pondok pesantren. Kesejahteraan guru tidak diambil dari SPP, melainkan dari hasil usaha pondok yang dikelola oleh para nadzir.

\section{Kesimpulan}

Pengelolaan wakaf produktif yang dikembangkan oleh Pondok Modern Darussalam Gontor ditopang oleh beberapa aspek, yaitu aspek SDM nadzir, aspek penghimpunan harta wakaf, aspek penggunaan harta wakaf dan aspek distribusi wakaf. Untuk mencetak SDM nadzir yang unggul, Pondok Modern mengembangkan pola kaderisasi dan mencanangkan wakaf diri/jiwa. Sedangkan pada aspek penghimpunan, harta wakaf yang dihimpun adalah harta yang memiliki nilai ekonomis. Selain itu, wakif menyerahkan sepenuhnya peruntukan 
harta wakaf kepada nadzir. Penggunaan harta wakaf dilakukan dengan pendekatan protektif, yang hasil keuntungannya digunakan untuk kemajuan pondok.

\section{Daftar Pustaka}

DEKS Bank Indonesia dan DES FEB UNAIR. 2016. "Seri Ekonomi Dan Keuangan Syariah, Wakaf: Pengaturan Dan Tata Kelola Yang Efektif." Jakarta.

Huda, Miftahul. 2012. "Wakaf Dan Kemandirian Pesantren Dari Tebuireng Hingga Gontor." Islamica : Jurnal Studi Keislaman 7 (1).

Kementrian Agama Republik Indonesia Direktorat Jendral Bimbingan Masyarakat Islam Direktorat Pemberdayaan Wakaf. 2013. "Pedoman Pengelolaan Dan Perkembangan Wakaf." Jakarta.

Marzuki, Peter Mahmud. 2007. Penelitian Hukum. Jakarta: Kencana Prenada Media Group. Nice, Durroh. 2016. "Wakaf Diri Pondok Modern Darussalam Gontor Dalam Persfektif Fiqh Dan UU. No. 41 Tahun 2004." Insklusif 1 (1).

Pondok Modern Darussalam Gontor. 2010. "Panca Jangka." 2010. https://www.gontor. ac.id/panca-jangka.

Zarkasyi, Abdullah Syukri. 2005. Manajemen Pesantren: Pengalaman Pondok Modern Gontor. Ponorogo: Trimurti Press. 